\title{
Correspondence
}

To the Editors

\section{Association between nutritional status and head lice infestation among school aged children: observation from rural border area of Thailand}

Sri Lanka Journal of Child Health, 2020; 49(2): 199-200

DOI: http://dx.doi.org/10.4038/sljch.v49i2.8979

(Key words: nutritional status, lice, children)

Many infections are common among the school aged children in developing countries. Hair infection is a problem that is sometimes overlooked $^{1}$. Head lice infestation is a common hair ectoparasite infection and is a public health problem for children in developing countries ${ }^{2}$. This infection is mainly seen in crowded areas with poor hygiene $^{3}$. In general, the infection is asymptomatic or has few symptoms and is therefore, easily underdiagnosed $^{3}$. An outbreak of head lice can occur among school aged children in a setting with poor sanitation ${ }^{4}$. Here, the authors report on a cross sectional school based study in rural area in Indochina namely Khokyang sub-district in North-
Eastern region of Thailand, a country in Southeast Asia (GPS location $5^{\circ} 00^{\prime} \mathrm{N} 103^{\circ} 07^{\prime} \mathrm{E} / 15^{\circ} \mathrm{N}$ $\left.103.11^{\circ} \mathrm{E} / 15 ; 103.11\right)$. The setting is the border area between Cambodia and Thailand. High prevalence of paediatric malnutrition is reported in this setting ${ }^{5}$. An examination for head lice, parallel to nutritional status assessment, was performed in 2019 among 520 school aged children, who studied in primary school in this rural sub district. The association between nutritional status and head lice infestation among the studied children is shown in Table 1 . There is a significant correlation between nutritional status and head lice infestation $(\mathrm{p}=$ $0.015 ; \mathrm{p}<0.05)$.

Table 1: Nutritional status and head lice infestation among school aged children

\begin{tabular}{|l|c|c|}
\hline \multicolumn{1}{|c|}{ Status } & $\begin{array}{c}\text { With head lice infestation } \\
\text { Number (\%) }\end{array}$ & $\begin{array}{c}\text { Without head lice infestation } \\
\text { Number (\%) }\end{array}$ \\
\hline Overweight & $1(0.19 \%)$ & $17(3.27 \%)$ \\
Normal & $15(2.88 \%)$ & $280(53.85 \%)$ \\
Underweight & $25(4.81)$ & $182(35 \%)$ \\
\hline
\end{tabular}

The clinical association is interesting. Atambay et al showed the relationship between head lice infestation and intestinal helminthiasis. Since intestinal parasitic infestation is an important factor contributing to malnutrition ${ }^{6}$, there might be an inter-relationship between head lice infestation and abnormal nutritional status. In fact, the risk for head lice infestation increased in children in the lower socioeconomic group, which is a common group that has nutritional status abnormality and the common population affected by head lice? There might or might not be direct biological linkage between malnutrition and hair lice. Nevertheless, malnutrition is usually related to poor sanitation and poverty, which are known factors relating to poor hygiene that can lead to hair lice infestation. Although the prevalence of head lice infestation might be low among school aged children in developed area of Thailand (prevalence in a previous report $=0.27 \%)^{8}$, this study shows the existence of a problem in the remote border area in Indochina.

\section{References}

1. Coscione S, Kositz C, Marks M. Head lice: An under-recognized tropical problem. American Journal of Tropical Medicine and Hygiene 2017; 97(6):16367.

https://doi.org/10.4269/ajtmh.17-0656 PMid: 29187278 PMCid: PMC5805079

2. Smith $\mathrm{CH}$, Goldman RD. An incurable itch: head lice. Canadian Family Physician 2012; 58:839-41.

3. Chuard C. Pediculosis. Rev Med Suisse 2007; 3(128):2266, 2268-70, 2272.

4. Do-Pham G, Monsel G, Chosidow O. Lice. Seminars in Cutaneous Medicine and Surgery 2014; 33(3): 116-8. https://doi.org/10.12788/j.sder.0105 PMid: 25577849 
5. Wiwanitkit V, Sodsri P. Underweight schoolchildren in a rural school near the Thai-Cambodian border. Southeast Asian Journal of Tropical Medicine and Public Health 2003; 34:458-61.

6. Atambay M, Karaman O, Karaman U, Aycan O, Yoloğlu S, Daldal N. The frequency of intestinal parasites and head lice among students of the Akşemsettin Primary School for Deaf Students. Turkiye Parazitol Derg 2007; 31(1):62-5.

7. Burgess IF, Silverston P. Head lice. $B M J$ Clinical Evidence 2015; 2015 p ii: 1703.

8. Sagnuankiat S, Wanichsuwan $\mathrm{M}$, Bhunnachet E, Jungarat N, Panraksa K, Komalamisra C, et al. Health Status of Immigrant Children and Environmental Survey of Child Daycare Centers in Samut Sakhon Province, Thailand. Journal of Immigrant and Minority Health 2016; 18(1):21-7.

https://doi.org/10.1007/s10903-014-01460

PMid: 25502792

\footnotetext{
*Won Sriwijitalai ${ }^{1}$, Viroj Wiwanitkit ${ }^{2}$

${ }^{1}$ TWS Medical Center, Bangkok Thailand

${ }^{2}$ Visiting Professor, Hainan Medical University, China, Honorary Professor, Dr. DY Patil University, Pune, India, Visiting Professor, Faculty of Medicine, University of Nis, Serbia, Adjunct Professor, Joseph Ayobabalola University, Nigeria

*Correspondence: wonsriwi@gmail.com

iD orcid.org/ 0000-0002-9542-2008
} 